\title{
Tahapan penelitian
}

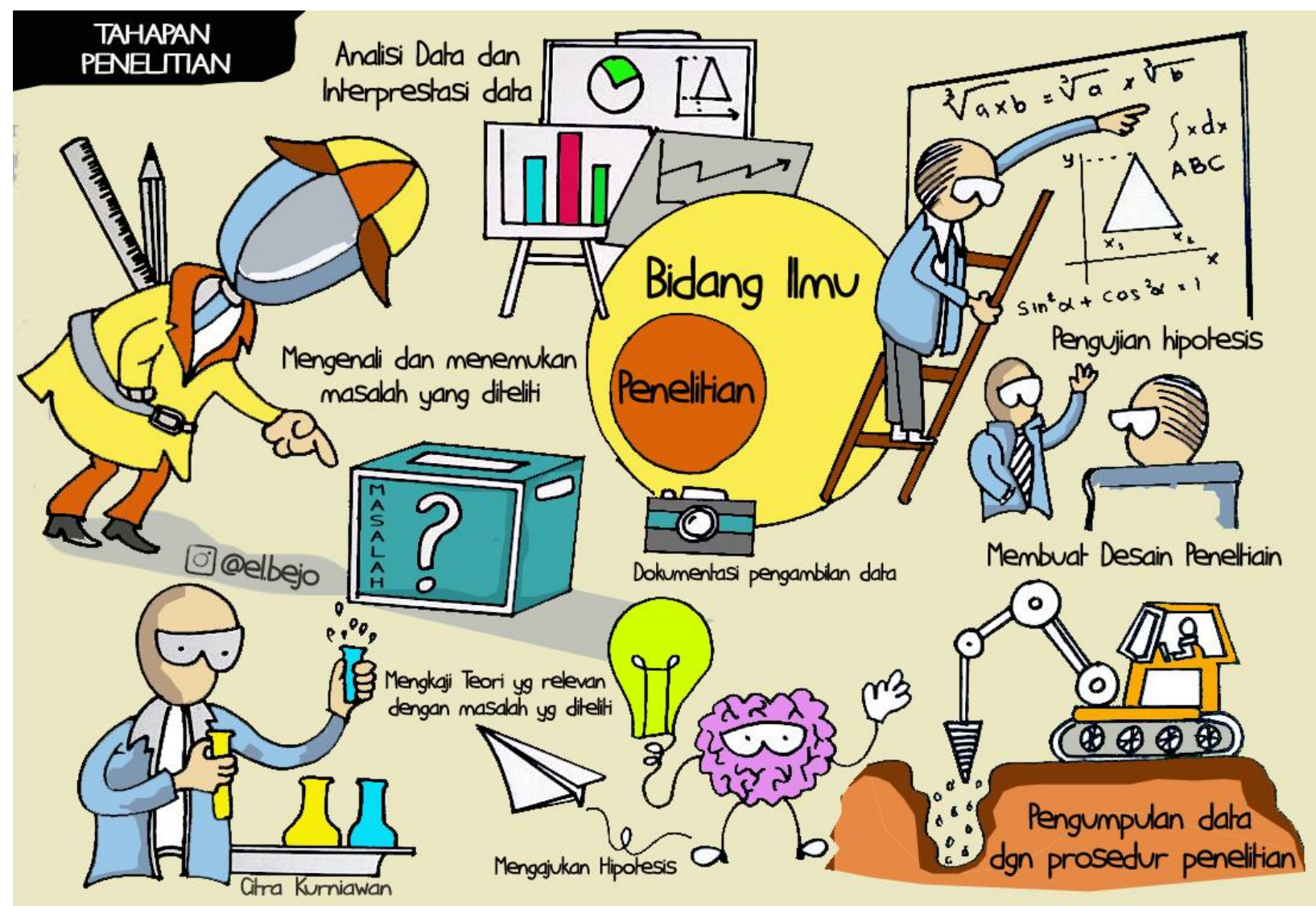

Tahapan penelitian terdiri dari beberapa tahap yaitu

1. Mengenali dan menentukan masalah yang diteliti

2. Mengkaji teori yang relevan dengan masalah yang akan diteliti

3. Mengajukan hipotesis

4. Membuat desain penelitian untuk menguji hipotesis

5. Mengumpulkan data dengan prosedur desain penelitian

6. Analisis data

7. Interprestasi data dan penarikan kesimpulan

Penulis: Citra Kurniawan 


\section{Hal yang Perlu Diperhatikan dalam Rumusan Masalah}

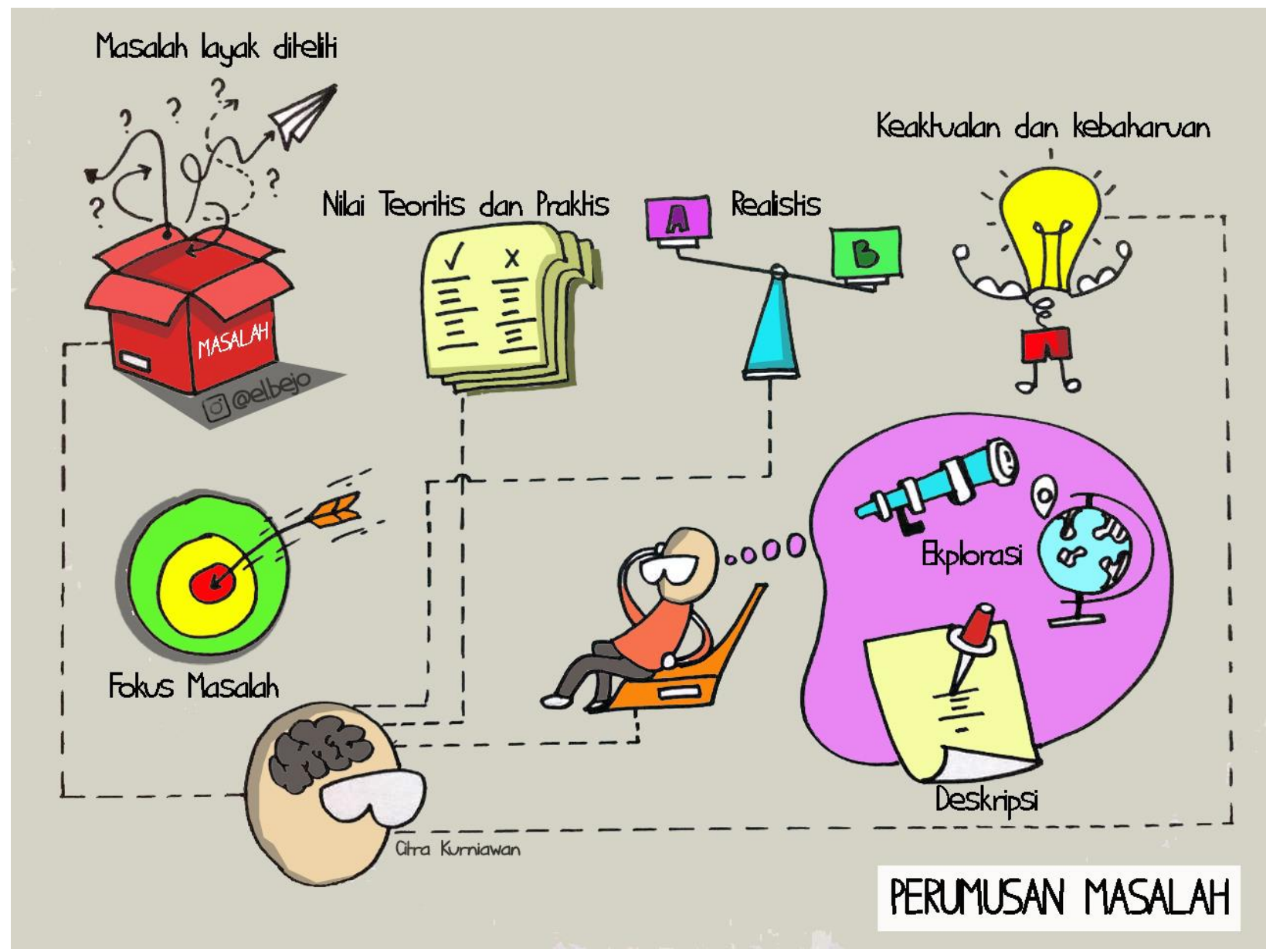

Pedoman dalam identifikasi masalah terbagi menjadi beberapa pertimbangan yaitu (1) Masalah yang diajukan dalam penelitian merupakan penelitian yang layak diteliti. (2) Mempunyai nilai teoritis dan praktis. (3) Realistis. (4) Identifikasi masalah mempertimbangkan keaktualan dan kebaharuan. Masalah yang diajukan dalam penelitian perlu proses identifikasi sehingga memfokuskan masalah merupakan keharusan. Fokus terhadap masalah adalah memilih dan menentukan masalah dan menguraikan masalah yang umum menjadi spesifik. Kategori tujuan dari perumusan masalah terbagi menjadi 2 yaitu deskriptif dan eksplorasi. Deskripsi bertujuan untuk menggambarkan penelitian secara verbal atau grafis terhadap peristiwa yang diamati. Sedangkan eksplorasi bertujuan untuk meneliti topik atau fokus yang relatif baru atau sama sekali belum pernah diteliti. Penelitian yang bersifat eksplorasi menunjukkan adanya keingintahuan yang besar peneliti untuk memahami atau mengkaji lebih dalam suatu fenomena tertentu.

Penulis: Citra Kurniawan airakurniawan@gmail.com 


\section{Tujuan melakukan tinjauan pustaka}

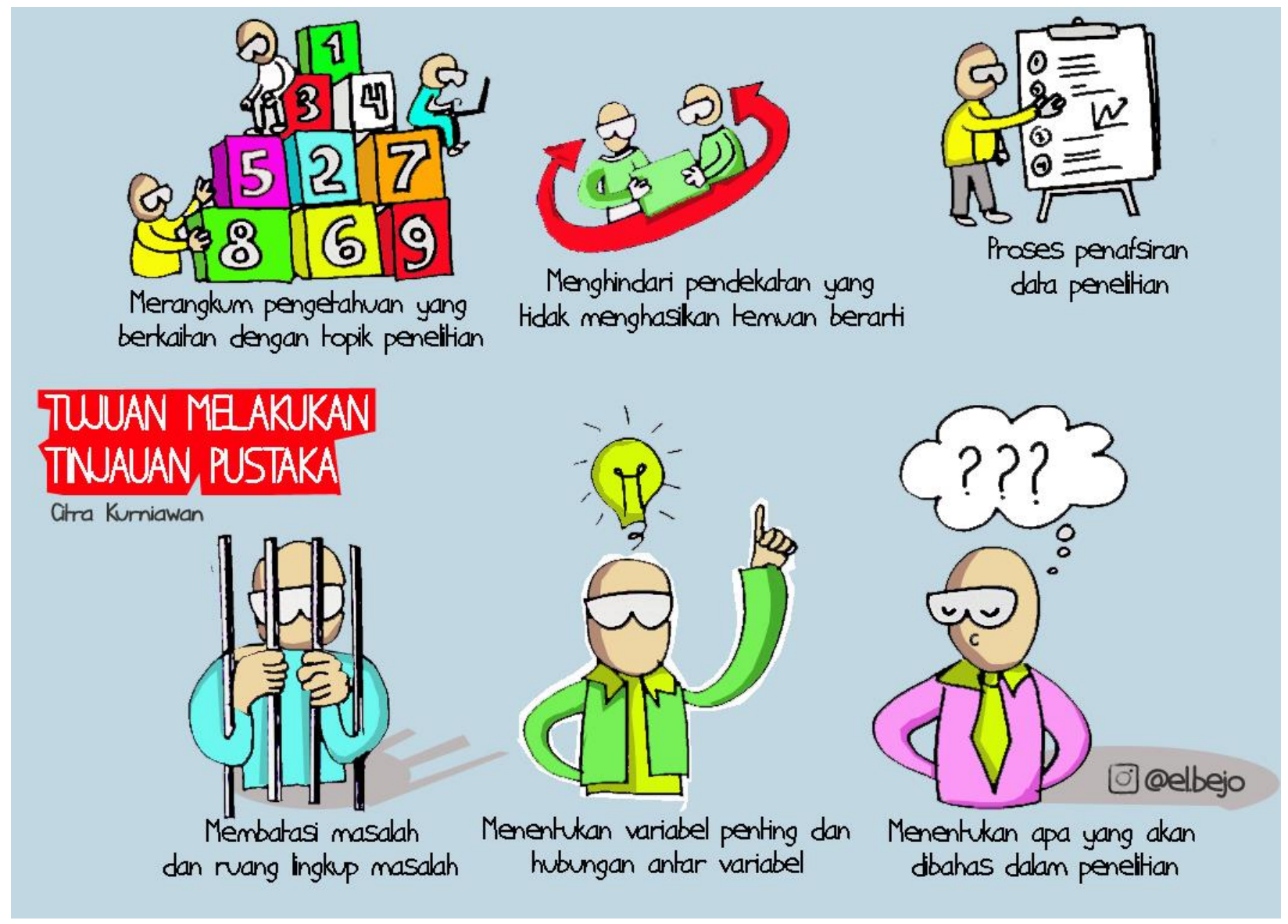

Tujuan melakukan tinjauan pustaka adalah sebagai berikut:

1. Membatasi masalah dan ruang lingkup penelitian

2. Menentukan variabel penelitan yang penting dan hubungan antar variabel

3. Mengetahui apa yang perlu diteliti dan dilakukan pada penelitian

4. Menghindari pendekatan yang tidak menghasilkan temuan berarti

5. Merangkum pengetahuan yang berkaitan dengan topik penelitian

6. Menemukan penjelasan untuk menafsirkan data penelitian

Penulis: Citra Kurniawan 


\section{Karateristik Hipotesisi yang Baik}

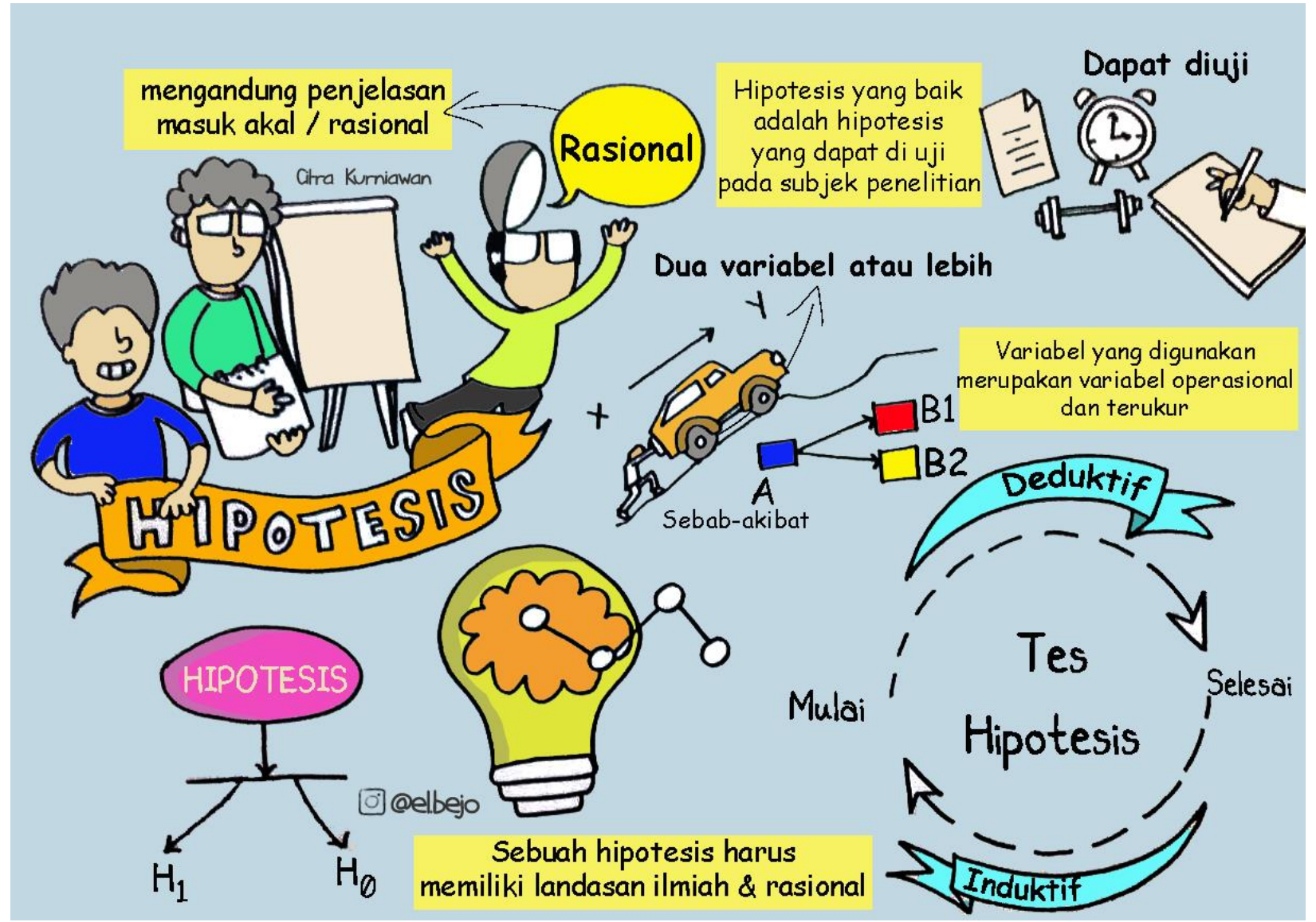

Pada bagian ini , saya akan mereview kembali tentang hipotesis karena pada sesi 4 , ada beberapa rekan-rekan yang belum memahami urgensi hipotesis pada penelitian.

Hipotesis harus memiliki landasan ilmiah dan rasional. Hipotesis mengindikasikan adanya kesinambungan dari penelitian sebelumnya dengan penelitian selanjutnya yang akan dilakukan peneliti. Hipotesis diharapkan dapat memberikan sumbangan terhadap teori dan praktik. Berikut karateristik hipotesis yang baik:

1. Rasional. Isi hipotesis berupa jawaban sementara mengenai fenomena tertentu dan mengandung penjelasan yang masuk akal / rasional.

2. Dua variabel / lebih. Hipotesis hendaknya mengandung hubungan kausal sebab akibat dan merupakan variabel operasional dan terukur. 
3. Dapat diuji. Hipotesis yang disusun harus dapat diuji di lapangan atau subjek penelitian.

Dalam proses penyusunan hipotesis, terdapat jenis hipotesis yang perlu dipahami.

- Hipotesis deduktif: Pola proses logika yang bermula dari hal yang bersifat umum mengarah ke hal yang spesifik.

- Hipotesis induktif: Pola proses logika yang bermula dari hal yang bersifat spesifik mengarah ke hal yang umum.

Penulis: Citra Kurniawan airakurniawan@gmail.com 